\title{
A new rapid titration protocol for lamotrigine that reduces the risk of skin rash
}

Yoonhyuk Jang ${ }^{1}$, Jangsup Moon ${ }^{1}$, Narae Kim ${ }^{1}$, Tae-Joon Kim², Jin-Sun Jun ${ }^{3}$, Yong-Won Shin $^{1}$, Hyeyeon Chang ${ }^{4}$, Hye Ryun Kang ${ }^{1}$, Soon-Tae Lee ${ }^{1}$, Keun-Hwa Jung ${ }^{1}$, Kyung-Il

Park $^{1}$, Ki-Young Jung ${ }^{1}$, Kon $\mathrm{Chu}^{1}$, and Sang Kun Lee ${ }^{1}$

${ }^{1}$ Seoul National University Hospital

${ }^{2}$ Ajou University School of Medicine and Graduate School of Medicine

${ }^{3}$ Kangnam Sacred Heart Hospital

${ }^{4}$ National Center for Mental Health

April 27, 2020

\begin{abstract}
Aims Lamotrigine is one of the most widely used antiepileptic drugs, but it has a critical issue of a skin rash if the starting dose is too high or the escalation rate is too rapid. We investigated the efficacy and safety of a novel and rapid titration protocol for lamotrigine that takes only 11 days to reach a daily dose of $200 \mathrm{mg}$. Methods We prospectively enrolled 33 adult patients (age 18-85) who were diagnosed with epilepsy and started lamotrigine administration for the first time at a single tertiary hospital. Our new protocol starts with a subthreshold dose of the drug and then administer a stepwise-incremental dose until reaching the full therapeutic dose within 11 days. Results Of 29 patients analyzed, only two (6.9\%) experienced idiosyncratic skin rash before the first follow-up visit at 2 weeks ( \pm 3 days). In addition, a therapeutic concentration was reached in more than $75 \%$ of studied patients after 2 weeks of lamotrigine administration Conclusion These findings demonstrate the value of the novel tolerance induction protocol for lamotrigine, which could widen the available application of lamotrigine in various situations.
\end{abstract}

\section{A new rapid titration protocol for lamotrigine that reduces the risk of skin rash}

Yoonhyuk Jang, $\mathrm{MD}^{1 *}$, Jangsup Moon, $\mathrm{MD}, \mathrm{PhD}^{1,2,{ }^{*}}$, Narae Kim, $\mathrm{PhD}^{1}$, Tae-Joon Kim, $\mathrm{MD}^{3}$, Jin-Sun Jun, $\mathrm{MD}^{4}$, Yong-Won Shin, $\mathrm{MD}^{5}$, Hyeyeon Chang, $\mathrm{MD}^{6}$, Hye-Ryun Kang MD, $\mathrm{PhD}^{7}$, Soon-Tae Lee, MD, $\mathrm{PhD}^{1}$, Keun-Hwa Jung, MD, PhD ${ }^{1}$, Kyung-Il Park, MD, $\mathrm{PhD}^{8}$, Ki-Young Jung, MD, PhD ${ }^{1}$, Kon Chu, MD, PhD ${ }^{1}$, Sang Kun Lee, $\mathrm{MD}, \mathrm{PhD}^{1}$

${ }^{1}$ Department of Neurology, Laboratory for Neurotherapeutics, Comprehensive Epilepsy Center, Biomedical Research Institute, Seoul National University Hospital, Seoul, South Korea

${ }^{2}$ Rare Disease Center, Seoul National University Hospital, Seoul, South Korea

${ }^{3}$ Department of Neurology, Ajou University School of Medicine, Suwon, South Korea

${ }^{4}$ Department of Neurology, Kangnam Sacred Heart Hospital, Hallym University College of Medicine, Seoul, South Korea

${ }^{5}$ Department of Neurosurgery, Seoul National University Hospital, Seoul, South Korea

${ }^{6}$ Department of Neurology, National Center for Mental Health, Seoul, South Korea

${ }^{7}$ Institute of Allergy and Clinical Immunology, Seoul National University Medical Research Center; Department of Internal Medicine, Seoul National University College of Medicine, Seoul, Korea 
${ }^{8}$ Department of Neurology, Seoul National University Hospital Healthcare System Gangnam Center, Seoul, South Korea

* These authors contributed equally to this study.

Character count for the title: 81

Total word count for the abstract: 183

Total word count for the manuscript: 2300

Number of references: 30

Number of tables: 2

Number of figures: 1

Running head: Rapid lamotrigine titration protocol

Correspondence:

Kon $\mathrm{Chu}, \mathrm{MD}, \mathrm{PhD}$

Department of Neurology, Seoul National University Hospital,

101 Daehak-ro, Jongno-gu, Seoul 110-744, South Korea

Tel.: +82-2-2072-1878/Fax: + 82-2-3672-7553

Email:stemcell.snu@gmail.com

and

Sang Kun Lee, MD, PhD

Department of Neurology, Seoul National University Hospital,

101 Daehak-ro, Jongno-gu, Seoul 110-744, Korea

Tel: +82-2-2072-2923/ Fax: +82-2-3672-7553

E-mail:sangkun2923@gmail.com

What is already known about this subject:

Lamotrigine has a high risk of cutaneous adverse reactions if the starting dose is too high or if the escalation is made too rapidly. Thus, the conventional titration protocol recommends to be slower to be safer, taking more than 8 weeks to reach the usual maintenance dose.

What this study adds:

We introduce a new lamotrigine titration protocol that takes only eleven days to reach the usual maintenance dose without increasing the risk of skin rash. By reducing the titration duration, this protocol can lead to an increase in lamotrigine prescription for various indications including frequent seizures and psychiatric diseases.

\section{Abstract}

Aims

Lamotrigine is one of the most widely used antiepileptic drugs, but it has a critical issue of a skin rash if the starting dose is too high or the escalation rate is too rapid. We investigated the efficacy and safety of a novel and rapid titration protocol for lamotrigine that takes only 11 days to reach a daily dose of $200 \mathrm{mg}$.

Methods 
We prospectively enrolled 33 adult patients (age 18-85) who were diagnosed with epilepsy and started lamotrigine administration for the first time at a single tertiary hospital. Our new protocol starts with a subthreshold dose of the drug and then administer a stepwise-incremental dose until reaching the full therapeutic dose within 11 days.

\section{Results}

Of 29 patients analyzed, only two $(6.9 \%)$ experienced idiosyncratic skin rash before the first follow-up visit at 2 weeks ( \pm 3 days). In addition, a therapeutic concentration was reached in more than $75 \%$ of studied patients after 2 weeks of lamotrigine administration

\section{Conclusion}

These findings demonstrate the value of the novel tolerance induction protocol for lamotrigine, which could widen the available application of lamotrigine in various situations.

\section{Introduction}

Lamotrigine is a widely used first-line antiepileptic drug (AED) in both adults and children with epilepsy.[1, 2] Especially in elderly epilepsy patients, it is the drug of choice and has the highest retention rate. [3] Moreover, lamotrigine is also a useful option for psychiatric disorders such as bipolar disorder. $[4,5]$ However, the major hindrance of lamotrigine administration has been the potentially life-threatening skin rash.[6, 7$]$ As an aromatic AED, lamotrigine has a high risk of inducing an idiosyncratic adverse reaction. [8] The risk of lamotrigine-induced skin rashes increase if the starting dose is too high or if the escalation is made too rapidly.[9] Thus, the conventional titration protocol has recommended to be slower to be safer, taking more than 8 weeks to reach the usual maintenance dose.[9-11]

Tolerance induction of a drug in patients who have drug allergies can be achieved by administration protocol adjustment.[12] The main strategy is to start with the administration of a suboptimal dose of the drug antigen and then to administer a stepwise-incremental dose until the full therapeutic dose is reached.[13] Various AEDs that are prone to skin rashes, including carbamazepine, oxcarbazepine, valproic acids, phenytoin, and phenobarbital, have been proven to be safely desensitized.[14-20] Moreover, even in chemotherapy, rituximab was also successfully desensitized by a stepwise-incremental protocol via the intravenous or intraperitoneal route.[21, 22] Likewise, with the same concept, tolerance to a certain drug has been successfully achieved even in drug- naïve patients who were at high risk but never experienced drug rashes before.[23] Jung and the colleagues classified patients according to the presence of a certain type of human leukocyte antigen (HLA) which is strongly associated with allopurinol-induced severe cutaneous reactions. The slow oral tolerance induction protocol of allopurinol was then applied to the high risk drug-naïve patients, showing a significant reduction in the skin rash.

We hypothesized that the idiosyncratic skin rash in response to lamotrigine could be prevented with the rapid tolerance induction protocol, which would consequently shorten the duration of the titration. Here, we introduce a new lamotrigine titration protocol that takes only eleven days to reach the usual maintenance dose without increasing the risk of skin rash.

\section{Method}

\section{Patient enrollments}

We prospectively enrolled adult patients (age 18-85) who were diagnosed with epilepsy and started lamotrigine administration for the first time at Seoul National University Hospital from July 2016 to November 2018. Patients who had ever been prescribed enzyme-inducing AEDs (phenytoin, phenobarbital, carbamazepine, oxcarbazepine), enzyme-inhibiting AED (valproic acid), or oral contraceptives or had ever experienced drug rashes were excluded.

\section{Clinical assessment}


This study was approved by the Institutional Review Board of the Seoul National University (IRB No 1605121-764), and was registered at ClinicalTrials.gov (NCT 03220256). Written informed consent was obtained from all patients.

Patients were asked to visit the outpatient clinic after two weeks ( \pm 3 days) from the protocol onset. When the patient experienced any adverse event before the $1^{\text {st }}$ follow-up visit, they were informed to report the issue to the researcher by phone. Cutaneous adverse events were evaluated according to the Common Terminology Criteria for Adverse Events (CTCAE) version 4.0. The extent of the skin lesion was calculated using the Lund \& Browder body surface chart. The primary outcome was defined as the occurrence of a skin rash until the $1^{\text {st }}$ follow-up. The secondary outcome was the severity of the skin rash, the lamotrigine serum level, and the occurrence of skin rash beyond 2 weeks of lamotrigine administration. The patients were disqualified from the study when they did not appear to a scheduled visit. Also, patients were dropped out from the study when they omitted three doses of two consecutive doses on their own discretion.

\section{Lamotrigine rapid tolerance induction protocol}

Lamotrigine was prescribed to the patients following an 11-day schedule for the rapid tolerance induction protocol (Table 1, Figure). The protocol started with a dose of $0.1 \mathrm{mg}$, and the next dose was escalated to 1.5-2.5 times the previous dose every 12 hours. From day 4, the same dose was given twice a day, and the daily dose of lamotrigine was escalated to 1.5-2 times the previous dose every day, reaching $100 \mathrm{mg}$ bid on day 11. After the 11th day, the dose was titrated according to the clinician's decision. Doses below 2.5mg were mixed with saccha lactose and prepared as powdered medicine at the hospital pharmacy.

Fluorescence-activated cell sorting analysis of regulatory $\mathbf{T}$ cells before and after the titration protocol

We evaluated fluorescence-activated cell sorting ( FACS) analysis to evaluate the proportion of regulatory $\mathrm{T}$ (Treg) cells among CD4+ helper $\mathrm{T}$ cells before the lamotrigine rapid titration and after the 2 weeks $( \pm 3$ days) of the $1^{\text {st }}$ follow-up visit because former studies have demonstrated the increase of the percentage of the total Treg cells after the tolerance induction of drugs.

The difference of the proportion of the Tregs before and after the lamotrigine rapid titration was analyzed with the Wilcoxon matched pairs signed-rank test. STATA 14 (StataCorp LLC., Texas, USA) was used for analysis, and a $p$-value $<.05$ was considered as statistically significant.

\section{Result}

\section{Patient characteristics}

Of the 33 patients who were enrolled in the current study, four patients (12\%) were disqualified; two patients were lost to follow-up, and two patients omitted lamotrigine more than 3 times without an agreement. Thus, twenty-nine patients (88\%) were ultimately analyzed (Table 2 ). Thirteen patients were males (44.8\%), and the median age was 34 years [interquartile range, $36-45$ years]. Twenty-four hours video electroencephalogram were performed for all patients; temporal lobe epilepsy was the most common diagnosis $(15,51.7 \%)$, followed by idiopathic generalized epilepsy $(8,27.6 \%)$. Seven patients $(24.1 \%)$ had taken an AED before lamotrigine administration, with levetiracetam being the most common. None of the patients had taken an aromatic AED, previously.

\section{Idiosyncratic skin rash occurrence after lamotrigine rapid titration}

Two patients (2 of 29,6.9\%) experienced idiosyncratic skin rash before the $1^{\text {st }}$ follow-up visit (Table 2). One patient (Patient ID 1) had a relatively mild rash on the arms and one leg (BSA 18\%) on day 14 (on lamotrigine dose $100 \mathrm{mg}$ bid). The skin lesion disappeared after changing the AED to levetiracetam. The other patient (Patient ID 2) experienced acute-onset maculopapular rash on the whole body (BSA $>95 \%$ ) on day 17 (on lamotrigine dose $100 \mathrm{mg}$ bid) just after the administration of propranolol due to newly diagnosed postural tachycardia syndrome. The rash subsided the next day after withholding lamotrigine and propranolol. 


\section{Serum lamotrigine level and long-term assessment}

At the $1^{\text {st }}$ follow-up visit, the serum lamotrigine level was checked in 22 patients (75.9\%) (Table 2). The mean value of the serum lamotrigine level was $3.85 \mathrm{mcg} / \mathrm{mL}$ (SD 2.07). Among them, 17 patients (77.2\%) successfully reached the therapeutic serum level $(2.5-15 \mathrm{mcg} / \mathrm{mL})[24]$ within 2 weeks.

Beyond the $1^{\text {st }}$ follow-up visit at 2 weeks ( \pm 3 days), a delayed-onset skin rash appeared in three patients (Patient ID 3, 4, and 5, 10.3\%). One patient (Patient ID 3) had a maculopapular rash on the neck, body, arms, and legs (BSA 41\%) on day 19 just after increasing the dose of lamotrigine to $150 \mathrm{mg}$ twice a day. One patient (Patient ID 4) experienced a maculopapular rash on almost the whole body below the neck (BSA 91\%) on day 24 (on lamotrigine $100 \mathrm{mg}$ bid), but it was unclear whether the rash was induced by lamotrigine. While the dosage of lamotrigine was maintained at $100 \mathrm{mg}$ twice a day for nearly two weeks, common cold drugs (codeine, bromhexine, chlorpheniramine, and roxithromycin were given to the patient since 3 days before the rash occurrence. After withholding the cold medications and lamotrigine, the rash subsided. The other patient (Patient ID 5) reported a very mild skin rash on the thigh on day 28; therefore, the lamotrigine was prescribed continuously (on $100 \mathrm{mg}$ bid). Afterward, celecoxib was added as the painkiller for an orthopedic reason. After 9 days, the skin rash on the hand and thigh (BSA 6\%) flared up; therefore, lamotrigine and celecoxib were stopped. The rash disappeared soon after the discontinuation. However, none of the patients experienced Stevens-Johnson syndrome or toxic epidermal necrosis.

\section{The proportion of regulatory $T$ cells among the total CD4+ $T$ cells before and after the titration protocol}

FACS analysis of the Treg cells was performed before and after the lamotrigine rapid titration in 10 patients. The mean value of the percentage of Treg before the titration was $4.64 \%$ (SD 0.64) and that of Treg after the titration was $4.00 \%$ (SD 0.93). No statistically significant alteration of the Treg proportion was observed after the lamotrigine tolerance induction $(\mathrm{p}=0.333)$.

\section{Discussion}

Here, we demonstrated a new titration protocol for lamotrigine that could be faster and safer than the conventional titration protocol. The conventional protocol starts with a dose of $25 \mathrm{mg}$ per day and doubles it every one to two weeks, requiring up to 8 weeks to reach the maintenance dose of $200 \mathrm{mg}$ per day. Our rapid protocol dramatically reduces the time required for titration and reaches $200 \mathrm{mg}$ per day in 11 days without severe cutaneous adverse reactions.

The new titration protocol was safer in terms of cutaneous adverse reactions when compared to the conventional titration protocol. Only $6.9 \%(2 / 29)$ of the patients experienced skin rash during rapid titration, which was lower than the rate of cutaneous adverse reactions after lamotrigine in the Korean population, which has been reported to be up to $22.5 \%$ (23/102).[25] Furthermore, one of these patients experienced idiosyncratic skin rash just after the administration of propranolol, suggesting that lamotrigine may not be the true cause of the skin rash. Additional 3 patients encountered skin rash beyond the $1^{\text {st }}$ follow-up visit; one patient experienced skin rash after the dose escalation of lamotrigine to $150 \mathrm{mg}$ bid, and two patients experienced skin rash after the administration of a potentially causative drug (roxithromycin and celecoxib, respectively). We think the skin rash could have been preventable by further protocol refinement in the first patient and the lamotrigine was not the culprit drug in the latter two patients.

The new titration protocol allows the lamotrigine serum levels to rise rapidly to the therapeutic range in a fairly short time. At the $1^{\text {st }}$ follow-up visit, 2 weeks ( \pm 3 days) after lamotrigine administration, the therapeutic concentration was reached in more than three-quarters of the measured patients. Two patients (Patient ID 14 and 23) with frequent seizures at baseline (5 times/week and 2 times/week, respectively) experienced significant seizure reduction by reaching the therapeutic concentration (serum lamotrigine level 4.6 and $5.5 \mathrm{mcg} / \mathrm{mL}$, respectively) within 2 weeks of lamotrigine administration. Conventionally, patients who start taking lamotrigine would be exposed to sustained risk of seizure for nearly two months until the lamotrigine reach the therapeutic levels. Therefore, combined prescription of other AEDs are often required 
during the titration period. Thus, the currnet protocol would be extremely useful in severe epilepsy patients with frequent seizures, and it will shorten the duration of bridging therapy during the conversion from other AEDs to lamotrigine. Moreover, this protocol can be useful in the acute management of psychiatric disorders such as bipolar disorder in an acute stage of a manic state.

Desensitization protocols, originally developed for the prevention of drug allergies, can also be effective when starting a new drug. Desensitization protocols induce temporary tolerance to a drug in patients who have experienced drug hypersensitivity.[26] The protocols start with a suboptimal dose of the drug antigen at fixed time intervals, followed by stepwise incremental increases to full therapeutic doses, and they have been successful at avoiding skin rashes in response to many drugs, including AEDs and antibiotics.[27, 28] Desensitization protocols can be refined by increasing the step of incremental dose, which normally induces fewer symptoms.[29] The mechanism of desensitization is not fully understood, but it is thought to be achieved by reducing the mast cell and basophil response or by increasing drug-specific Treg cells, [13, 29, 30] so that it could also be effective in drug-naïve patients. Jung et al. demonstrated that the desensitization protocol was useful during the first administration of allopurinol in high-risk patients.[23] In line with this, our study demonstrates that tolerance to lamotrigine can be achieved by applying the rapid desensitization protocol to patients who start receiving lamotrigine.

However, the exact mechanism of tolerance induction is worth being investigated. We assessed the proportion of Treg cells among the total CD4+ T cells before and after the protocol in some patients, which did not demonstrate any meaningful alterations. This shows the different result with other studies of AED desensitization having the increase of the proportion of the total Tregs after the tolerance induction. The discrepancy could come from the fundamental difference of the immune reactions, in that our tolerance induction targets the naive immune cells, but the former studies are the desensitization protocol against the memory $\mathrm{T}$ cells, which the patients already had had the immunity against the AEDs. Thus, for the tolerance induction, the percentage of the antigen-specific Treg cells, not that of the total Treg cells, could have mattered to the tolerance induction. The alteration of drug-specific $\mathrm{T}$ cells and mast cell/basophil functions after titration should be investigated in the future.

This study is limited by the small number of patients and its uncontrolled and open-label design. Subsequent studies should be conducted in a larger number of patients. Further protocol refinement may increase the safety of the protocol, and strategies for increasing lamotrigine to a higher daily dose (beyond $100 \mathrm{mg}$ bid) should be investigated.

In conclusion, our study demonstrated a successful rapid tolerance induction protocol for lamotrigine in patients with epilepsy. It significantly reduced the duration of titration to 11 days with noticeable safety, which will be extremely helpful in patients with frequent seizures who require prompt dose escalation of AEDs. Moreover, this protocol can lead to an increase in lamotrigine prescription for various indications. Thus, additional refinement and validation of the protocol should be investigated in a larger trial in the near future.

\section{Acknowledgements}

This study was supported by the Seoul National University Hospital Research Fund (0420170820). We appreciate the support of Hong Won Jang and Yoon Sook Cho at the SNUH Clinical trial center pharmacy and the hospital pharmacy.

\section{Conflicts of Interests}

The authors declare no conflict of interests.

\section{Ethical Publication Statement}

We confirm that we have read the Journal's position on issues involved in ethical publication and affirm that this report is consistent with those guidelines.

\section{Data Availability Statement}


The data that support the findings of this study are available from the corresponding author upon reasonable request.

\section{Author Contributions}

Y.J, and J.M. wrote and revised the manuscript. Y.J, N.K., and J.M. analyzed the data. Y.J, J.M, T-J. K, J-S. J., Y-W. S, H.C, S-T. L, K-I. P, K-Y. J, K.C, and S.K.L collected clinical data. J.M, H-R. K, K.C, and S.K.L provided study concepts and revised the manuscript. J.M, S-T. L, K-H. J, K-I. P, K-Y. J, K.C. and S.K.L. provided materials and funding. K.C. and S.K.L. supervised the study. All authors reviewed the manuscript.

\section{References}

1. Kwan P, Brodie MJ. Effectiveness of First Antiepileptic Drug. Epilepsia 2001; 42: 1255-60.

2. Nevitt SJ, Sudell M, Weston J, Tudur Smith C, Marson AG. Antiepileptic drug monotherapy for epilepsy: a network meta-analysis of individual participant data. The Cochrane database of systematic reviews 2017; 12.

3. Arif H, Buchsbaum R, Pierro J, Whalen M, Sims J, Resor SR, Bazil CW, Hirsch LJ. Comparative effectiveness of 10 antiepileptic drugs in older adults with epilepsy. Archives of neurology 2010; 67: 408-15.

4. Prabhavalkar KS, Poovanpallil NB, Bhatt LK. Management of bipolar depression with lamotrigine: an antiepileptic mood stabilizer. Frontiers in Pharmacology 2015; 6: 242.

5. Geddes JR, Calabrese JR, Goodwin GM. Lamotrigine for treatment of bipolar depression: independent meta-analysis and meta-regression of individual patient data from five randomised trials. British Journal of Psychiatry 2009; 194: 4-9.

6. Moon J, Park HK, Chu K, Sunwoo JS, Byun JI, Lim JA, Kim TJ, Shin JW, Lee ST, Jung KH. The HLA-A* 2402/C w* 0102 haplotype is associated with lamotrigine-induced maculopapular eruption in the K orean population. Epilepsia 2015; 56: e161-e67.

7. Kim B-K, Jung J-W, Kim T-B, Chang Y-S, Park H-S, Moon J, Lee S-T, Jung K-H, Jung K-Y, Chu K. HLA-A* 31: 01 and lamotrigine-induced severe cutaneous adverse drug reactions in a Korean population. Annals of Allergy, Asthma \& Immunology 2017; 118: 629-30.

8. Wang X-q, Xiong J, Xu W-H, Yu S-y, Huang X-s, Zhang J-t, Tian C-l, Huang D-h, Jia W-q, Lang S-y. Risk of a lamotrigine-related skin rash: Current meta-analysis and postmarketing cohort analysis. Seizure 2015; 25: 52-61.

9. Wong IC, Mawer GE, Sander JW. Factors influencing the incidence of lamotrigine-related skin rash. The Annals of pharmacotherapy 1999; 33: 1037-42.

10. John AM. Rash in Adult and Pediatric Patients Treated with Lamotrigine. Can J Neurological Sci J Can Des Sci Neurologiques 1998; 25: S14-S18.

11. Alan HG, Frank MCB, Martin JB, Joseph MD, Michael SD, John MP, Alan R, Robert SS, Edwin T. Lamotrigine-Associated Rash: Risk/Benefit Considerations in Adults and Children. Epilepsia 1999; 40: 985-91.

12. Khan DA, Solensky R. Drug allergy. Journal of Allergy and Clinical Immunology 2010; 125: S126-S37.e1.

13. Akdis CA. Therapies for allergic inflammation: refining strategies to induce tolerance. Nature Medicine 2012; 18: 736 .

14. Lee B, Yu H, Kang E-S, Lee M, Lee J. Human Leukocyte Antigen Genotypes and Trial of Desensitization in Patients With Oxcarbazepine-Induced Skin Rash: A Pilot Study. Pediatric Neurology 2014; 51: $207-14$. 
15. Smith H, Newton R. ADVERSE REACTIONS TO CARBAMAZEPINE MANAGED BY DESENSITISATION. The Lancet 1985; 325: 753.

16. Eames P. ADVERSE REACTIONS TO CARBAMAZEPINE MANAGED BY DESENSITISATION. The Lancet 1989; 333: 509-10.

17. Toker O, Tal Y, Horev L, Shmoeli D, Gilboa T. Valproic acid hypersensitivity and desensitization. Developmental Medicine \& Child Neurology 2015; 57: 1076-78.

18. Okumura A, Tsuge I, Kubota T, Kurahashi H, Natsume J, Negoro T, Watanabe K. Phenytoin desensitization monitored by antigen specific $\mathrm{T}$ cell response using carboxyfluorescein succinimidyl ester dilution assay. European Journal of Paediatric Neurology 2007; 11: 385-88.

19. Itomi S, Okumura A, Ikuta T, Negoro T, Watanabe K. Phenytoin desensitization in a child with symptomatic localization-related epilepsy. Brain and Development 2007; 29: 121-23.

20. Butte MJ, Dodson B, Dioun A. Pentobarbital desensitization in a 3-month-old child. Allergy and asthma proceedings 2004; 25: 225-27.

21. Aydogan M, Yologlu N, Gacar G, Uyan Z, Eser I, Karaoz E. Successful rapid rituximab desensitization in an adolescent patient with nephrotic syndrome: Increase in number of Treg cells after desensitization. Journal of Allergy and Clinical Immunology 2013; 132: 478-80.

22. Castells MC, Tennant NM, Sloane DE, Hsu IF, Barrett NA, Hong DI, Laidlaw TM, Legere HJ, Nallamshetty SN, Palis RI, Rao JJ, Berlin ST, Campos SM, Matulonis UA. Hypersensitivity reactions to chemotherapy: Outcomes and safety of rapid desensitization in 413 cases. Journal of Allergy and Clinical Immunology 2008; 122: 574-80.

23. Jung J-W, Kim D-K, Park H-W, Oh K-H, Joo K-W, Kim Y-S, Ahn C, Lee K, Cho S-H, Min K-U, Kang H-R. An effective strategy to prevent allopurinol-induced hypersensitivity by HLA typing. Genetics in Medicine 2015; 17: 807.

24. Johannessen SI, Battino D, Berry DJ, Bialer M, Kramer G, Tomson T, Patsalos PN. Therapeutic Drug Monitoring of the Newer Antiepileptic Drugs. Therapeutic Drug Monitoring 2003; 25: 347-63.

25. Tak H-J, Ahn J-H, Kim K-W, Kim Y, Choi S-W, Lee K-Y, Park E, Bhang S-Y. Rash in Psychiatric and Nonpsychiatric Adolescent Patients Receiving Lamotrigine in Korea: A Retrospective Cohort Study. Psychiatry Investigation 2012; 9: 174-79.

26. Castells M. Desensitization for drug allergy. Current Opinion in Allergy and Clinical Immunology 2006; 6: $476-81$.

27. Legendre DP, Muzny CA, Marshall GD, Swiatlo E. Antibiotic hypersensitivity reactions and approaches to desensitization. Clinical infectious diseases 2013; 58: 1140-48.

28. Mani R, Monteleone C, Schalock PC, Truong T, Zhang XB, Wagner ML. Rashes and Other Hypersensitivity Reactions Associated with Antiepileptic Drugs: A Review of Current Literature. Seizure 2019.

29. Liu A, Fanning L, Chong H, Fernandez J, Sloane D, Sancho-Serra M, Castells M. Desensitization regimens for drug allergy: state of the art in the 21st century. Clinical \& Experimental Allergy 2011; 41: 1679-89.

30. Scherer K, Brockow K, Aberer W, Gooi JHC, Demoly P, Romano A, Schnyder B, Whitaker P, Cernadas JSR, Bircher AJ. Desensitization in delayed drug hypersensitivity reactions - an EAACI position paper of the Drug Allergy Interest Group. Allergy 2013; 68: 844-52.

Figure. The protocols of lamotrigine titration. Scheme of the conventional and rapid lamotrigine titration protocols. The number inside the box indicates the daily dose of lamotrigine. The conventional protocols start with a dose of $12.5 \mathrm{mg}$ bid for the first and second weeks and double it to $25 \mathrm{mg}$ bid in the 
third and fourth weeks. From the fifth week, the daily dose is increased by $50 \mathrm{mg}$ every one to two weeks, requiring up to 8 weeks to reach the maintenance dose of $200 \mathrm{mg}$ per day. This conventional protocol is for patients not taking cytochrome $\mathrm{P}$ inducer or inhibitor. Our rapid titration protocol starts with a dose of 0.1 $\mathrm{mg}$, and the next dose is escalated to 1.5-2.5 times the previous dose every 12 hours. From day 4, the same dose is given twice a day, and the daily dose is escalated to 1.5-2 times the previous dose every day, reaching $100 \mathrm{mg}$ bid on day 11. After day 11, the dose is titrated according to the clinician's decision.

\begin{tabular}{ll}
\hline Table 1. Tolerance induction protocol for lamotrigine & Table 1 . Tolerance induction protocol for lamotrigir \\
\hline Day & Dose \\
1 & $0.1-0.25 \mathrm{mg} \mathrm{q} 12 \mathrm{~h}$ \\
2 & $0.5-0.75 \mathrm{mg} \mathrm{q} 12 \mathrm{~h}$ \\
3 & $-1-1.5 \mathrm{mg} \mathrm{q} 12 \mathrm{~h}$ \\
4 & $2.5 \mathrm{mg} \mathrm{bid}$ \\
5 & $5 \mathrm{mg} \mathrm{bid}$ \\
6 & $10 \mathrm{mg} \mathrm{bid}$ \\
7 & $15 \mathrm{mg} \mathrm{bid}$ \\
8 & $25 \mathrm{mg} \mathrm{bid}$ \\
9 & $50 \mathrm{mg}$ bid \\
10 & $75 \mathrm{mg} \mathrm{bid}$ \\
$11-$ & $100 \mathrm{mg}$ bid \\
bid = twice a day; $\mathrm{q} 12 \mathrm{~h}=$ every 12 hours. & bid $=$ twice a day; q12h $=$ every 12 hours. \\
\hline
\end{tabular}

\begin{tabular}{|c|c|c|c|c|c|c|c|c|c|}
\hline $\begin{array}{l}\text { Table } \\
2 . \\
\text { Clini- } \\
\text { cal } \\
\text { re- } \\
\text { sponse of } \\
\text { pa- } \\
\text { tients } \\
\text { with }\end{array}$ & $\begin{array}{l}\text { Table } \\
2 . \\
\text { Clini- } \\
\text { cal } \\
\text { re- } \\
\text { sponse of } \\
\text { pa- } \\
\text { tients } \\
\text { with }\end{array}$ & $\begin{array}{l}\text { Table } \\
2 . \\
\text { Clini- } \\
\text { cal } \\
\text { re- } \\
\text { sponse of } \\
\text { pa- } \\
\text { tients } \\
\text { with }\end{array}$ & $\begin{array}{l}\text { Table } \\
2 . \\
\text { Clini- } \\
\text { cal } \\
\text { re- } \\
\text { sponse of } \\
\text { pa- } \\
\text { tients } \\
\text { with }\end{array}$ & $\begin{array}{l}\text { Table } \\
2 . \\
\text { Clini- } \\
\text { cal } \\
\text { re- } \\
\text { sponse of } \\
\text { pa- } \\
\text { tients } \\
\text { with }\end{array}$ & $\begin{array}{l}\text { Table } \\
2 . \\
\text { Clini- } \\
\text { cal } \\
\text { re- } \\
\text { sponse of } \\
\text { pa- } \\
\text { tients } \\
\text { with }\end{array}$ & $\begin{array}{l}\text { Table } \\
2 . \\
\text { Clini- } \\
\text { cal } \\
\text { re- } \\
\text { sponse of } \\
\text { pa- } \\
\text { tients } \\
\text { with }\end{array}$ & $\begin{array}{l}\text { Table } \\
2 . \\
\text { Clini- } \\
\text { cal } \\
\text { re- } \\
\text { sponse of } \\
\text { pa- } \\
\text { tients } \\
\text { with }\end{array}$ & $\begin{array}{l}\text { Table } \\
2 . \\
\text { Clini- } \\
\text { cal } \\
\text { re- } \\
\text { sponse of } \\
\text { pa- } \\
\text { tients } \\
\text { with }\end{array}$ & $\begin{array}{l}\text { Table } \\
2 . \\
\text { Clini- } \\
\text { cal } \\
\text { re- } \\
\text { sponse of } \\
\text { pa- } \\
\text { tients } \\
\text { with }\end{array}$ \\
\hline $\begin{array}{l}\text { epilepsy af } \\
\text { ter } \\
\text { toler- } \\
\text { ance } \\
\text { induc- } \\
\text { tion }\end{array}$ & $\begin{array}{l}\text { fepilepsy a } \\
\text { ter } \\
\text { toler- } \\
\text { ance } \\
\text { induc- } \\
\text { tion }\end{array}$ & $\begin{array}{l}\text { f-epilepsy af } \\
\text { ter } \\
\text { toler- } \\
\text { ance } \\
\text { induc- } \\
\text { tion }\end{array}$ & $\begin{array}{l}\text { f-epilepsy a } \\
\text { ter } \\
\text { toler- } \\
\text { ance } \\
\text { induc- } \\
\text { tion }\end{array}$ & $\begin{array}{l}\text { f-epilepsy a } \\
\text { ter } \\
\text { toler- } \\
\text { ance } \\
\text { induc- } \\
\text { tion }\end{array}$ & $\begin{array}{l}\text { f-epilepsy a } \\
\text { ter } \\
\text { toler- } \\
\text { ance } \\
\text { induc- } \\
\text { tion }\end{array}$ & $\begin{array}{l}\text { f-epilepsy a } \\
\text { ter } \\
\text { toler- } \\
\text { ance } \\
\text { induc- } \\
\text { tion }\end{array}$ & $\begin{array}{l}\text { f-epilepsy af } \\
\text { ter } \\
\text { toler- } \\
\text { ance } \\
\text { induc- } \\
\text { tion }\end{array}$ & $\begin{array}{l}\text { f-epilepsy af } \\
\text { ter } \\
\text { toler- } \\
\text { ance } \\
\text { induc- } \\
\text { tion }\end{array}$ & $\begin{array}{l}\text { f-epilepsy } \\
\text { ter } \\
\text { toler- } \\
\text { ance } \\
\text { induc- } \\
\text { tion }\end{array}$ \\
\hline$\overline{\text { ID }}$ & Sex/Age & Diagnosis & $\begin{array}{l}\text { Combined } \\
\text { AED }\end{array}$ & $\begin{array}{l}\text { Idiosyncr } \\
\text { Skin } \\
\text { rash }^{*} \\
\text { (days } \\
\text { after } \\
\text { LMT) }\end{array}$ & $\begin{array}{l}\text { tididT } \\
\text { level at } \\
1^{\text {st }} \text { FU }\end{array}$ & $\begin{array}{l}\text { Skin } \\
\text { rash } \\
\text { beyond } \\
1^{\text {st }} \text { FU } \\
\text { (days } \\
\text { after } \\
\text { LMT) }\end{array}$ & $\begin{array}{l}\text { Rash } \\
\text { Ty- } \\
\text { pe/BSA(\% }\end{array}$ & $\begin{array}{l}\text { Potential } \\
\text { Trigger- } \\
\text { oind } \\
\text { factor }\end{array}$ & $\begin{array}{l}\text { LMT } \\
\text { discon- } \\
\text { tinua- } \\
\text { tion } \\
\text { related } \\
\text { to rash } \\
\text { (daily } \\
\text { dose at } \\
\text { rash) }\end{array}$ \\
\hline 1 & $\mathrm{~F} / 45$ & $\begin{array}{l}\text { Lt. } \\
\text { OLE }\end{array}$ & & $\begin{array}{l}+(14 \\
\text { d) }\end{array}$ & 6.9 & - & Maculopapı & $\mathrm{ul}($ ary $/ 18$ & $\begin{array}{l}+(100 \\
\mathrm{mg} \\
\mathrm{bid})\end{array}$ \\
\hline
\end{tabular}




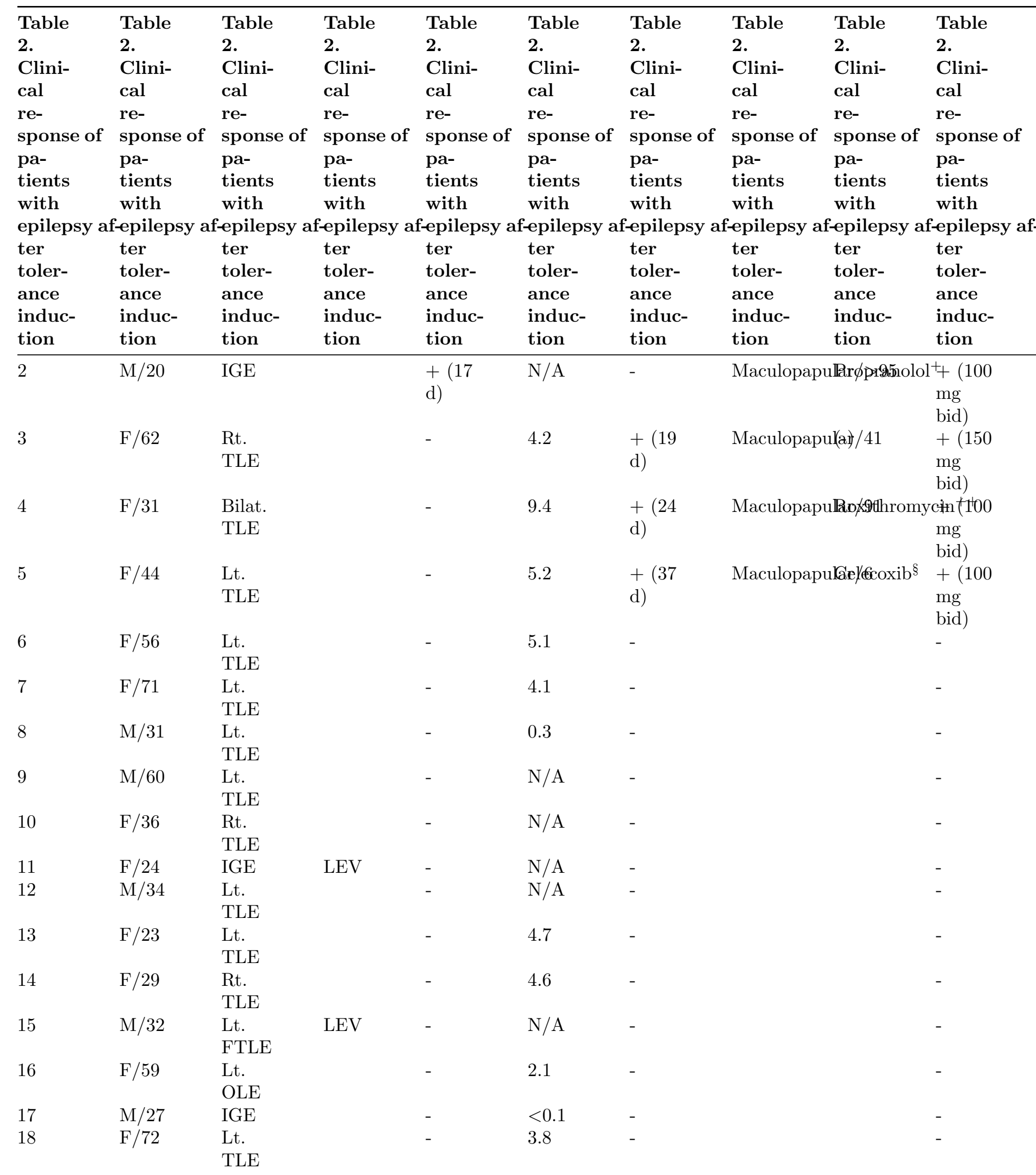




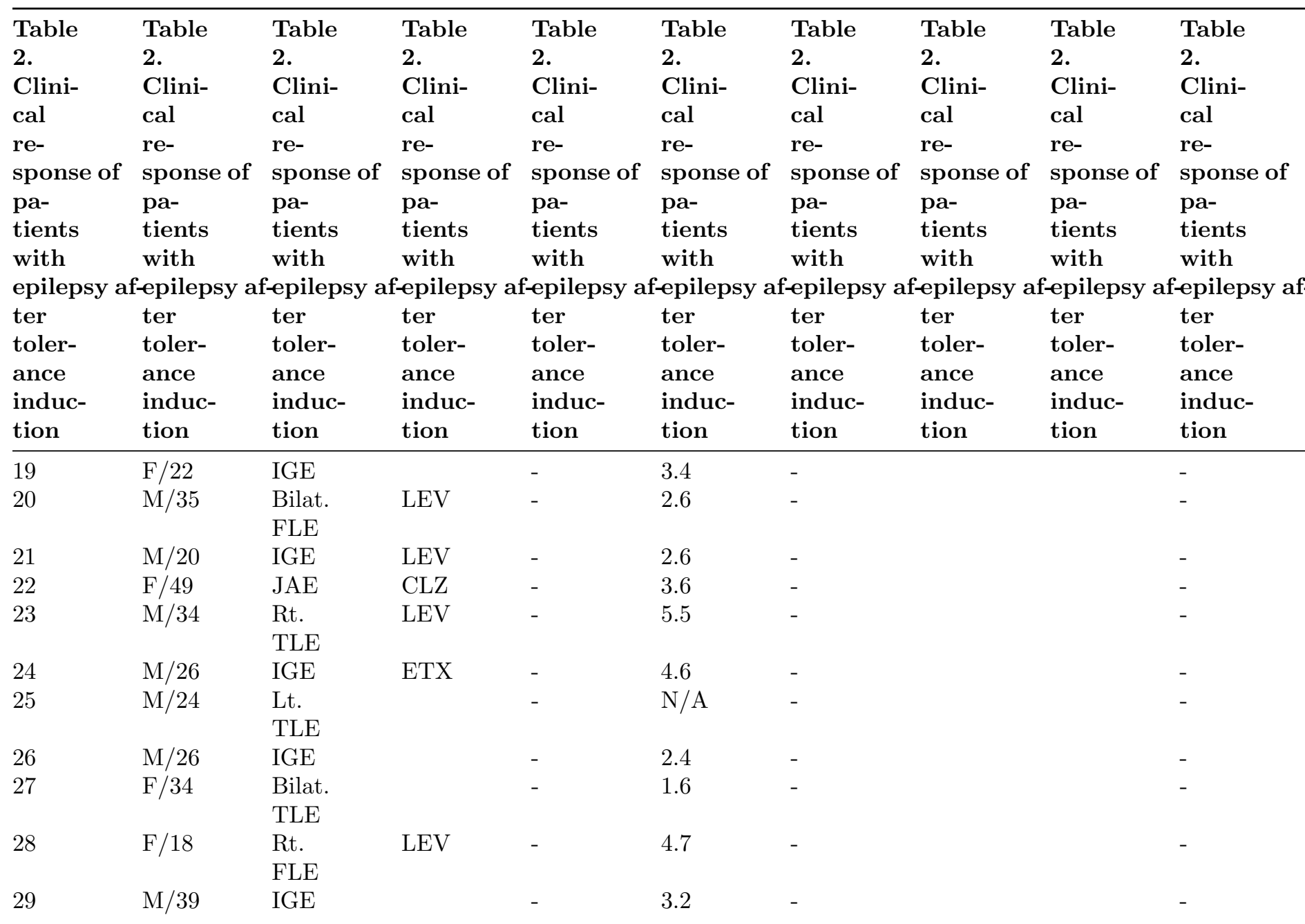




\begin{tabular}{|c|c|c|c|c|c|c|c|c|c|}
\hline Table & Table & Table & Table & Table & Table & Table & Table & Table & Table \\
\hline 2. & 2. & 2. & 2. & 2. & 2. & 2. & 2. & 2. & 2. \\
\hline $\begin{array}{l}\text { Clini- } \\
\text { cal }\end{array}$ & $\begin{array}{l}\text { Clini- } \\
\text { cal }\end{array}$ & $\begin{array}{l}\text { Clini- } \\
\text { cal }\end{array}$ & $\begin{array}{l}\text { Clini- } \\
\text { cal }\end{array}$ & $\begin{array}{l}\text { Clini- } \\
\text { cal }\end{array}$ & $\begin{array}{l}\text { Clini- } \\
\text { cal }\end{array}$ & $\begin{array}{l}\text { Clini- } \\
\text { cal }\end{array}$ & $\begin{array}{l}\text { Clini- } \\
\text { cal }\end{array}$ & $\begin{array}{l}\text { Clini- } \\
\text { cal }\end{array}$ & $\begin{array}{l}\text { Clini- } \\
\text { cal }\end{array}$ \\
\hline re- & re- & re- & re- & re- & re- & re- & re- & re- & re- \\
\hline sponse of & sponse of & sponse of & sponse of & sponse of & sponse of & sponse of & sponse of & sponse of & sponse of \\
\hline pa- & pa- & pa- & pa- & pa- & pa- & pa- & pa- & pa- & pa- \\
\hline tients & tients & tients & tients & tients & tients & tients & tients & tients & tients \\
\hline with & with & with & with & with & with & with & with & with & with \\
\hline epilep & -epilep: & f-epileps & epileps & fepileps & epilepsy & f-epileps & fepileps & f-epilep & f-epilepsy \\
\hline & ter & ter & ter & ter & ter & ter & ter & ter & ter \\
\hline toler- & toler- & toler- & toler- & toler- & toler- & toler- & toler- & toler- & toler- \\
\hline ance & ance & ance & ance & ance & ance & ance & ance & ance & ance \\
\hline $\begin{array}{l}\text { induc- } \\
\text { tion }\end{array}$ & $\begin{array}{l}\text { induc- } \\
\text { tion }\end{array}$ & $\begin{array}{l}\text { induc- } \\
\text { tion }\end{array}$ & $\begin{array}{l}\text { induc- } \\
\text { tion }\end{array}$ & $\begin{array}{l}\text { induc- } \\
\text { tion }\end{array}$ & $\begin{array}{l}\text { induc- } \\
\text { tion }\end{array}$ & $\begin{array}{l}\text { induc- } \\
\text { tion }\end{array}$ & $\begin{array}{l}\text { induc- } \\
\text { tion }\end{array}$ & $\begin{array}{l}\text { induc- } \\
\text { tion }\end{array}$ & $\begin{array}{l}\text { induc- } \\
\text { tion }\end{array}$ \\
\hline $\mathrm{AED}$, & AED & AED & AED, & Cx & t & $\Delta \mathrm{FD}$ & $\mathrm{AFD}$ & $\mathrm{AED}$ & EL \\
\hline antiepilep- & antiepilep- & antiepilep- & antiel & antie & antic & lep- & lep- & ilep- & anti \\
\hline & & & & & & & & & tic \\
\hline drug; & drug; & drug; & drug; & drug; & drug; & drug; & drug; & drug; & drug; \\
\hline BSA, & BSA, & BSA, & BSA, & BSA, & BSA, & BSA, & BSA, & BSA, & BSA, \\
\hline body & body & body & body & body & body & body & body & body & body \\
\hline surface & surface & surface & surface & surface & surface & ace & sur & $\mathrm{su}$ & sur \\
\hline area; & area; & area; & area; & area; & area; & area; & area; & area; & area; \\
\hline FU, & FU, & FU, & FU, & FU, & FU, & $\mathrm{FU}$ & $\mathrm{FU}$, & FU, & FU, \\
\hline $\begin{array}{l}\text { follow- } \\
\text { up; }\end{array}$ & $\begin{array}{l}\text { follow- } \\
\text { up; }\end{array}$ & $\begin{array}{l}\text { follow- } \\
\text { up: }\end{array}$ & $\begin{array}{l}\text { follow- } \\
\text { up: }\end{array}$ & $\begin{array}{l}\text { follow- } \\
\text { up: }\end{array}$ & $\begin{array}{l}\text { follow- } \\
\text { up: }\end{array}$ & $\begin{array}{l}\text { follow- } \\
\text { up: }\end{array}$ & $\begin{array}{l}\text { follow- } \\
\text { up: }\end{array}$ & $\begin{array}{l}\text { follow- } \\
\text { up: }\end{array}$ & $\begin{array}{l}\text { follow- } \\
\text { up: }\end{array}$ \\
\hline LMT, & LMT, & LMT, & LMT, & LMT, & LMT, & LMT, & LMT, & LMT, & LMT, \\
\hline mot- & lamot- & lamot- & lamot- & lamot- & lam & lan & lan & lan & lan \\
\hline gine; & rigine; & rigine; & rigine; & rigin & rigin & rigi & rigi & rig & $\mathrm{ri \xi}$ \\
\hline $\mathrm{EV}$ & LEV, & LEV, & LEV, & LEV, & LEV, & LET & LEV, & $\mathrm{LE}$ & LEV, \\
\hline ve- & leve- & leve- & leve- & lev & lev & lev & lev & lex & le \\
\hline rac- & tirac- & tirac- & tira & tira & tira & tir & tir & til & $\mathrm{ti}$ \\
\hline am; & etam; & etam; & ets & ets & et & et & et & et & et \\
\hline $\mathrm{TX}$ & ETX, & ETX, & ETX, & ETX, & ETX, & $\mathrm{E}^{r}$ & ETX, & $\mathrm{E}^{r}$ & ETX, \\
\hline ho- & etho- & etho- & etho & eth & eth & etl & etl & et & et \\
\hline x- & sux- & sux- & sux & $\mathrm{su}$ & su & $\mathrm{su}$ & $\mathrm{su}$ & $\mathrm{su}$ & su \\
\hline nide; & imide; & imide; & imide; & imide; & imide; & $\mathrm{im}$ & imide; & $\mathrm{im}$ & de; \\
\hline CLZ, & CLZ, & CLZ, & CLZ, & CLZ & CLZ, & CL & CLZ, & CL & CLZ, \\
\hline $\begin{array}{l}\text { clon- } \\
\text { azepam; }\end{array}$ & $\begin{array}{l}\text { clon- } \\
\text { azepam; }\end{array}$ & $\begin{array}{l}\text { clon- } \\
\text { azepa }\end{array}$ & $\begin{array}{l}\text { clon- } \\
\text { azepa }\end{array}$ & $\begin{array}{l}\text { clon- } \\
\text { azepa }\end{array}$ & $\begin{array}{l}\text { clon- } \\
\text { azepa }\end{array}$ & $\begin{array}{l}\text { clon- } \\
\text { azepa }\end{array}$ & $\begin{array}{l}\text { clon- } \\
\text { azepar }\end{array}$ & clo & clon- \\
\hline IGE, & IGE, & IGE, & IGE, & IGE, & IGE, & IGE, & IGE, & IGE, & IGE, \\
\hline idio- & idio- & idio- & idio- & idio- & & & & id & id \\
\hline athic & pathic & & & & & & & & $n$ \\
\hline gener- & gener- & gener- & gener- & gener- & gener- & gener- & gener- & gener- & gener- \\
\hline ized & alized & alized & alized & alized & alized & alized & alized & aliz & alize \\
\hline epilepsy; & epil & epilepsy; & epilepsy; & epilepsy; & epilepsy; & epilepsy; & epilepsy; & epil & epil \\
\hline FLE, & FLE, & FLE, & FLE, & FLE, & FLE, & FLE, & FLE, & FLE, & FLE, \\
\hline frontal & frontal & frontal & frontal & frontal & frontal & fro & fro & fro & fro \\
\hline lobe & lobe & lobe & lobe & lobe & lobe & lobe & lobe & lobe & lobe \\
\hline epilepsy; & epilepsy; & epilepsy; & epilepsy; & epilepsy; & epilepsy; & epilepsy; & epilepsy; & epilepsy; & epilepsy; \\
\hline TLE, & TLE, & TLE, & TLE, & TLE, & TLE, & TLE, & TLE, & TLE, & TLE, \\
\hline tempo- & tempo- & tempo- & tempo- & tempo- & tempo- & tempo- & tempo- & tempo- & tempo- \\
\hline al lobe & ral lobe & ral lobe & ral lobe & ral lobe & ral lobe & ral lobe & ral lobe & ral lobe & ral lobe \\
\hline epilepsy; & epilepsy; & epilepsy; & epilepsy; & epilepsy; & epilepsy; & epilepsy; & epilepsy; & epilepsy; & epilepsy; \\
\hline FTLE, & FTLE, & FTLE, & FTLE, & FTLE, & FTLE, & FTLE, & FTLE, & FTLE, & FTLE, \\
\hline fron- & fron- & fron- & fron- & fron- & fron- & fron- & fron- & fron- & fro \\
\hline $\begin{array}{l}\text { totem- } \\
\text { poral }\end{array}$ & $\begin{array}{l}\text { totem- } \\
\text { poral }\end{array}$ & $\begin{array}{l}\text { totem- } \\
\text { poral }\end{array}$ & $\begin{array}{l}\text { totem- } \\
\text { poral }\end{array}$ & $\begin{array}{l}\text { totem- } \\
\text { poral }\end{array}$ & $\begin{array}{l}\text { totem- } \\
\text { poral }\end{array}$ & $\begin{array}{l}\text { totem- } \\
\text { poral }\end{array}$ & $\begin{array}{l}\text { totem- } \\
\text { poral }\end{array}$ & $\begin{array}{l}\text { totem- } \\
\text { poral }\end{array}$ & $\begin{array}{l}\text { totem- } \\
\text { poral }\end{array}$ \\
\hline epilepsy; & epilepsy; & epilepsy; & epilepsy; & epilepsy; & epilepsy; & epilepsy; & epilepsy; & epilepsy; & epilepsy; \\
\hline
\end{tabular}




\begin{tabular}{llllllllll}
\hline Table & Table & Table & Table & Table & Table & Table & Table & Table & Table \\
2. & 2. & 2. & 2. & 2. & 2. & 2. & 2. & 2. & 2. \\
Clini- & Clini- & Clini- & Clini- & Clini- & Clini- & Clini- & Clini- & Clini- & Clini- \\
cal & cal & cal & cal & cal & cal & cal & cal & cal & cal \\
re- & re- & re- & re- & re- & re- & re- & re- & re- & re- \\
sponse of & sponse of & sponse of & sponse of & sponse of & sponse of & sponse of & sponse of & sponse of & sponse of \\
pa- & pa- & pa- & pa- & pa- & pa- & pa- & pa- & pa- & pa- \\
tients & tients & tients & tients & tients & tients & tients & tients & tients & tients \\
with & with & with & with & with & with & with & with & with & with \\
epilepsy & af-epilepsy & af-epilepsy & af-epilepsy & af-epilepsy & af-epilepsy af-epilepsy af-epilepsy af-epilepsy af-epilepsy af \\
ter & ter & ter & ter & ter & ter & ter & ter & ter & ter \\
toler- & toler- & toler- & toler- & toler- & toler- & toler- & toler- & toler- & toler- \\
ance & ance & ance & ance & ance & ance & ance & ance & ance & ance \\
induc- & induc- & induc- & induc- & induc- & induc- & induc- & induc- & induc- & induc- \\
tion & tion & tion & tion & tion & tion & tion & tion & tion & tion \\
\hline
\end{tabular}

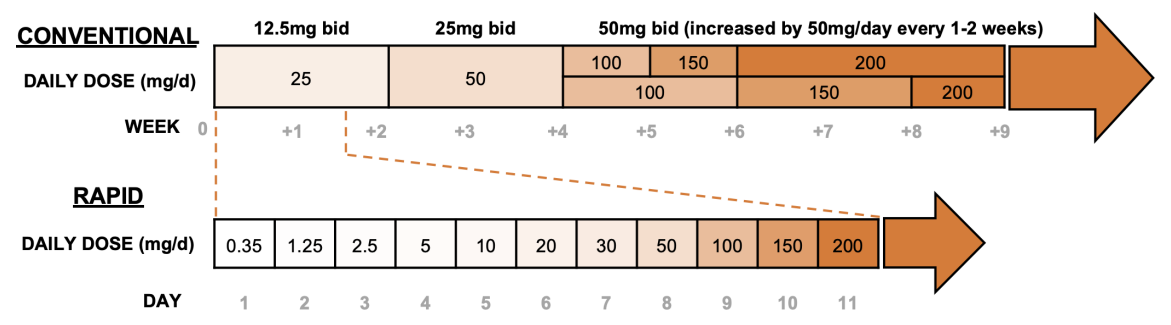

